\title{
The genetic legacy of lower sea levels: does the confluence of rivers during the last glacial maximum explain the contemporary distribution of a primary freshwater fish (Pseudobarbus burchelli, Cyprinidae) across isolated river systems?
}

\author{
Ernst R. Swartz ${ }^{\star}$, Albert Chakona, Paul H. Skelton, Paulette Bloomer
}

\begin{abstract}
The primary freshwater fish Pseudobarbus burchelli (Smith 1841) occurs across four presently isolated river systems in the south-western cape floristic region of South Africa. Mitochondrial DNA cytochrome $b$ (701 base pairs) and control region (601 base pairs) genes were sequenced to assess the evolutionary history of $P$. burchelli and evaluate the role of climatic and landscape changes in shaping patterns of genetic variation in this species. We identified three historically isolated lineages in P. burchelli: a widespread lineage that occurs across three isolated river systems and two geographically restricted lineages. The results were evaluated against predictions of the confluence of river systems during low sea levels of the last glacial maximum. Occurrence of the widespread Breede lineage in the Duiwenhoks River system is consistent with reconstructed palaeoriver systems. However, the occurrence of this lineage in the Goukou river system that formed part of the eastern Gourits-Goukou palaeoriver system can only be explained by translocation or
\end{abstract}

E. R. Swartz $\left(^{*}\right) \cdot$ A. Chakona $\cdot$ P. H. Skelton South African Institute for Aquatic Biodiversity, Private Bag 1015, Grahamstown 6140, South Africa e-mail: e.swartz@saiab.ac.za

E. R. Swartz · P. Bloomer

Molecular Ecology and Evolution Programme, Department of Genetics, University of Pretoria, Pretoria 0002, South Africa a recent river capture or episodic inundation of low drainage divides. Extreme ecological gradients or the potential presence of instream physical barriers could have prevented an exchange of lineages between the Breede and Heuningnes river systems.

Keywords Sea levels, Last glacial maximum, Migration, Palaeorivers, Phylogeography, South Africa

\section{Introduction}

The distribution of primary freshwater taxa in multiple isolated river systems has been attributed to drainage rearrangements (e.g. Brito et al., 1997; Waters \& Wallis, 2000; Mesquita et al., 2001; Craw et al., 2007; Swartz et al., 2007; Burridge et al., 2008), sea-level regressions (e.g. Ketmaier et al., 2004; Swartz et al., 2007, 2009), intermittent freshwater connections (e.g. Burridge et al., 2008) and freshwater plumes into estuarine and marine environments (e.g. de Bruyn et al., 2004; Wong et al., 2004). Southern Africa experienced major sea-level fluctuations throughout the Tertiary Period (Siesser \& Dingle, 1981). The last major transgression occurred during the middle Miocene and lasted until the late Pliocene when sea levels ranged from $+200 \mathrm{~m}$ to over $+300 \mathrm{~m}$ along the south coast of South Africa (Butzer \& Helgren, 1972; Siesser \& Dingle, 1981). During this time, lowland areas and smaller river systems would have drowned, 
while larger river systems would have been severely fragmented (Fig. 1). Later transgressions apparently never reached more than $30 \mathrm{~m}$ above present-day sea levels (Butzer \& Helgren, 1972; Rogers, 1985).

The most recent major sea-level regression occurred during the last glacial maximum (LGM) about 18,000 years ago, when the coastline was about $130 \mathrm{~m}$ below the present-day levels (Tankard, 1976; Rogers, 1985; Ramsay \& Cooper, 2002). A major offshore feature of the area where $P$. burchelli occurs is the Agulhas Bank. This is a shallow area of the continental shelf that would have been exposed during lower sea levels (Fig. 1). Based on palaeoriver courses that were reconstructed by Swartz et al. (2009), using the bathymetry of South African Navy Charts, seismic profiling of offshore sediments by Birch (1980) and reviews published on offshore stratigraphical, sedimentological and bathymetric studies (Dingle \& Rogers, 1972; Dingle et al., 1987), it is proposed that exposure of the Agulhas Bank would have allowed adjacent rivers to coalesce before reaching the $-130 \mathrm{~m}$ sea level, forming two major historical river systems (Fig. 1). The Breede

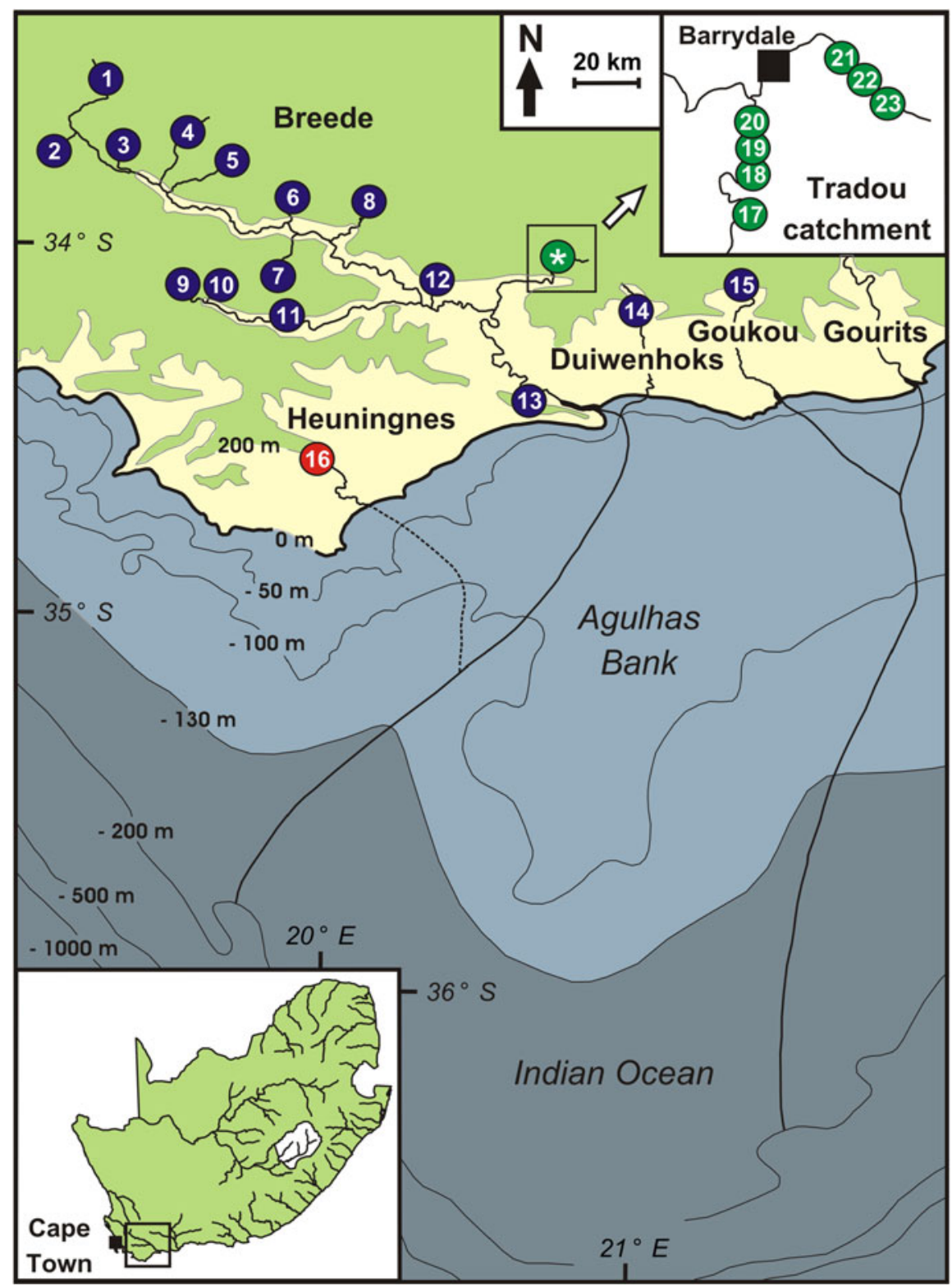

Fig. 1 Map of the Agulhas Bank region of the southern coast of South Africa where P. burchelli samples were collected (Breede lineage $=$ blue circles $;$ Heuningnes lineage $=$ red circle ; Tradou lineage $=$ green circles $)$. Currently isolated river systems and possible LGM palaeoriver courses based on the geological literature (solid lines according to Dingle and Rogers (1972) o r dashed lines based on the available bathymetry) are also shown. Insert maps show the Tradouw catchment with collection localities and the position of the study area in relation to South Africa 
and Duiwenhoks river systems would have formed a western palaeoriver system, whereas according to Birch (1980) and Dingle \& Rogers (1972), the Goukou River system would have had a common confluence with the Gourits River system to form an eastern palaeoriver system. The Heuningnes River system would have had a common confluence with the Breede and Duiwenhoks river systems before reaching the $-130 \mathrm{~m}$ sea level, unless it flowed in a more westerly direction compared to the direction proposed in Fig. 1.

Molecular studies have revealed the impact of the CFR's complex geological and climatic history on the evolution of the region's freshwater ichthyofauna. Waters \& Cambray (1997) suggested that confluence during lower sea levels could explain the close relationship between Galaxias zebratus populations from the Krom and Gamtoos river systems, but could not discount the recent river capture as an explanation. Bloomer \& Impson (2000) proposed that the occurrence of P. burgi in the presently isolated Berg and Verlorenvlei river systems could be due to changes in the course of the Berg River system and that sea-level changes could have played a role. Swartz et al. (2007, 2009) proposed that the confluence of river systems during periods of lower sea levels is the most plausible explanation for the close relationships between Pseudobarbus populations across presently isolated river systems in the CFR, based on reconstructions of possible palaeoriver systems during the LGM. They also suggested that river capture could explain the occurrence of closely related lineages in river systems that did not share a common confluence during periods of lower sea levels. A recent study by Chakona et al. (2013) revealed that intermittent freshwater connections through inundation of low drainage divides could have played an important role in allowing a newly identified galaxiid to attain its contemporary wide geographical range across the CFR. Building on this research, the present study adds to our understanding of the processes that have shaped the evolutionary history of the CFR's primary freshwater fishes by investigating what role lower sea levels during the LGM played in shaping the geographical distribution of genetic diversity in $P$. burchelli.

Pseudobarbus burchelli is the second most widely distributed redfin species in the CFR, occurring across four presently isolated river systems, namely the Heuningnes, Breede, Duiwenhoks and Goukou (Skelton, 1988). The Breede is the largest of these river systems and drains inland areas beyond the coastal ranges of the southern and south-western Cape Fold Mountains. The Duiwenhoks and Goukou river systems are much smaller and do not penetrate the coastal ranges of the Cape Fold Mountains. Pseudobarbus burchelli populations in the Breede, Duiwenhoks and Goukou river systems are presently isolated in upland tributaries that originate almost entirely in Table Mountain sandstones. These clear and oligotrophic mountain streams have low mineral and suspended materials (Day et al., 1998), and are the typical habitat for most of the redfin species. In contrast, the Heuningnes River system flows over gentle gradient, its water is eutrophic and carries high mineral and suspended materials, because it drains over Bokkeveld marine sediments and Sandveld sands (Keyser, 1998). Very little is known about the range of $P$. burchelli before anthropogenic impacts, particularly the introduction of bass species from North America (Micropterus salmoides, M. dolomieu and M. punctulatus) and the sharp-tooth catfish (Clarias gariepinus) from further north in Africa that now dominate the main stem areas of the rivers. It is likely that, like other redfins, the historical range of $P$. burchelli has shrunk significantly (Skelton, 1987, 1988). The only other redfin species that occurs in more river systems is $P$. afer, but four major lineages with strong geographical affinities have been found in this species (Swartz et al., 2007).

Here, we consider the role of sea-level regression as an important driver of the biogeographical patterns of the primary freshwater taxa in the CFR. Lower sea levels would have allowed several neighbouring river systems to have a common confluence before reaching the sea (Fig. 1). Freshwater taxa are proposed to have used these connections to expand their ranges to adjacent river systems (e.g. as shown in Swartz et al., 2007). Under this hypothesis, we expect to find shallow genetic divergence between rivers that are proposed to have shared a common confluence during the LGM.

The specific aims of the present study were firstly to assess genetic differentiation in mtDNA sequences of $P$. burchelli to determine the degree to which populations are geographically structured. The study investigated the evolutionary history of $P$. burchelli by testing the hypothesis outlined above. The present study has conservation relevance because effective conservation management should allow evolutionary 
processes that have shaped current intraspecific diversity to continue into the future (Moritz, 1999, 2002; Crandall et al., 2000). Pseudobarbus burchelli populations are in decline, mainly due to predation by alien fishes, habitat degradation and excessive water abstraction. Findings of this study will therefore help to prioritise areas of high conservation importance.

\section{Materials and methods}

\section{Sampling}

A total of 46 individuals were collected and analysed from 23 localities throughout the distribution range of $P$. burchelli. Of these, 46 individuals were analysed from 22 localities for mtDNA control region and 41 individuals from 22 localities were analysed for mtDNA cytochrome $b$ (Table 1; Fig. 1). Fishes were collected using a $3 \mathrm{~m}$ seine net or by snorkelling with a hand net. Either whole fish samples were stored in liquid nitrogen in the field and transferred to a $-70^{\circ} \mathrm{C}$ freezer upon returning to the laboratory or muscle, fin clips or whole fish samples were placed in EtOH (Department of Genetics, University of Pretoria). The voucher specimens were fixed in formalin and deposited in the national fish collection at the South African Institute for Aquatic Biodiversity (SAIAB) in Grahamstown.

\section{Measurement of geographical distances}

Geographical distance among sampled localities was measured along current river courses from a GIS layer (South African Department of Environmental Affairs and Tourism) and where necessary, along possible palaeoriver courses (Fig. 1). Distances between the western (Duiwenhoks, Breede and Heuningnes) and eastern (Gourits and Goukou) palaeoriver systems were measured along the $-200 \mathrm{~m}$ contour line. This contour is relatively close to the $-130 \mathrm{~m}$ contour that is used as a surrogate for the LGM's coastline and the edge of the continental shelf on the Agulhas Bank. Geographical distances among sampled localities were also measured along the present river courses and then along the present coastline, ignoring proposed palaeoriver systems. The $+200 \mathrm{~m}$ contour (Fig. 1) was used as an indication of which areas would have been available for occupation by redfins during the middle Miocene to the late Pliocene transgression (Butzer \& Helgren, 1972).
DNA extraction, amplification and sequencing

Genomic DNA was isolated from frozen or EtOHpreserved tissue using the standard protocols of chemical digestion and phenol/chloroform extraction (Sambrook et al., 1989). The mtDNA control region was amplified with the primers L16560 (5'-CCA AAG CCA GAA TTC TAA C-3') and H677 (5'-GTC GCG CAA AAA CCA AAG- $3^{\prime}$ ) that were specifically designed for cyprinids (Swartz et al., 2007). These primer names are according to the sequence positions of the $3^{\prime}$ base of each primer in the complete mtDNA genome sequence of Cyprinus carpio (Chang et al., 1994). The primers GluF (5'-AAC CAC CGT TGT ATT CAA CTA CAA- $\left.3^{\prime}\right)$ and ThrR (5'-ACC TCC GAT CTT CGG ATT ACA AGA CCG-3') from Machordom \& Doadrio (2001) were used to amplify almost the entire the mtDNA cytochrome $b$ gene. Reagents (apart from the primers) and conditions for amplification, purification and cycle sequencing were the same for the control region and cytochrome $b$.

Amplification was performed in $50 \mu \mathrm{l}$ volumes containing $1 \times$ buffer, $2 \mathrm{mM} \mathrm{MgCl} 2,0.2 \mathrm{mM}$ of each of the four nucleotides (Promega), $25 \mathrm{pmol}$ of each primer, $1.5 \mathrm{U}$ of Super-Therm DNA polymerase (Southern Cross Biotechnology) and 100-200 ng template DNA. Conditions for amplification involved an initial denaturation of $2 \mathrm{~min}$ at $94^{\circ} \mathrm{C}$, followed by 35 cycles of $30 \mathrm{~s}$ at $94^{\circ} \mathrm{C}, 30 \mathrm{~s}$ at $54^{\circ} \mathrm{C}, 45 \mathrm{~s}$ at $72^{\circ} \mathrm{C}$ and a final extension of $5 \mathrm{~min}$ at $72^{\circ} \mathrm{C}$. PCR products were purified using the High Pure ${ }^{\mathrm{TM}}$ PCR Product Purification Kit (Boehringer Mannheim), followed by elution in $\mathrm{ddH}_{2} \mathrm{O}$. Cycle sequencing was performed in $10 \mu \mathrm{l}$ volumes, with $2 \mu \mathrm{l}$ of the ABI PRISM Big Dye Terminator Cycle Sequencing Ready Reaction Kit (Applied Biosystems), $1.6 \mathrm{pmol}$ of a single primer (L16560 or H677 for control region or GluF or ThrR for cytochrome $b$ ) and $100 \mathrm{ng}$ of purified DNA as template. PCR cycling and cycle sequencing were performed in a Geneamp ${ }^{\circledR}$ PCR System 9700 (Applied Biosystems).

Nucleotide sequences were determined through ABI 377 or ABI 3100 automated sequencers (Applied Biosystems). Consensus sequences were obtained from the forward and reverse sequences and by comparing these to sequences from other individuals through alignment and inspection in Sequence Navigator 1.01 (Applied Biosystems). The consensus sequences were aligned using Clustal X (Thompson et al., 1997) and 
Table 1 Localities where $P$. burchelli specimens were collected

\begin{tabular}{|c|c|c|c|c|}
\hline Code & Locality & Latitude & Longitude & Date \\
\hline \multicolumn{5}{|c|}{ Breede River system } \\
\hline 1 & Koekedou & $33^{\circ} 21^{\prime} 30^{\prime \prime} \mathrm{S}$ & $19^{\circ} 17^{\prime} 00^{\prime \prime} \mathrm{E}$ & $24 / 03 / 2001$ \\
\hline 2 & Wit & $33^{\circ} 34^{\prime} 30^{\prime \prime} \mathrm{S}$ & $19^{\circ} 08^{\prime} 30^{\prime \prime} \mathrm{E}$ & $21 / 03 / 1998$ and $23 / 03 / 2001$ \\
\hline 3 & Jan Dutoits & $33^{\circ} 35^{\prime} 30^{\prime \prime} \mathrm{S}$ & $19^{\circ} 19^{\prime} 45^{\prime \prime} \mathrm{E}$ & $23 / 03 / 2001$ \\
\hline 4 & Hex & $33^{\circ} 31^{\prime} 50^{\prime \prime} \mathrm{S}$ & $19^{\circ} 32^{\prime} 25^{\prime \prime} \mathrm{E}$ & $23 / 03 / 2001$ \\
\hline 5 & Nuy & $33^{\circ} 37^{\prime} 45^{\prime \prime} \mathrm{S}$ & $19^{\circ} 41^{\prime} 00^{\prime \prime} \mathrm{E}$ & $19 / 03 / 2001$ \\
\hline 6 & Willem Nels & $33^{\circ} 45^{\prime} 25^{\prime \prime} \mathrm{S}$ & $19^{\circ} 52^{\prime} 05^{\prime \prime} \mathrm{E}$ & $19 / 03 / 2001$ \\
\hline 7 & Hoeks & $34^{\circ} 01^{\prime} 30^{\prime \prime} \mathrm{S}$ & $19^{\circ} 50^{\prime} 30^{\prime \prime} \mathrm{E}$ & $21 / 03 / 2001$ \\
\hline 8 & Kogmanskloof & $33^{\circ} 46^{\prime} 20^{\prime \prime} \mathrm{S}$ & $20^{\circ} 07^{\prime} 10^{\prime \prime} \mathrm{E}$ & $22 / 03 / 2001$ \\
\hline 9 & Baviaans & $34^{\circ} 02^{\prime} 10^{\prime \prime} \mathrm{S}$ & $19^{\circ} 33^{\prime} 30^{\prime \prime} \mathrm{E}$ & $12 / 03 / 2001$ \\
\hline 10 & Gobos & $34^{\circ} 02^{\prime} 20^{\prime \prime} \mathrm{S}$ & $19^{\circ} 37^{\prime} 10^{\prime \prime} \mathrm{E}$ & $12 / 03 / 2001$ \\
\hline 11 & Bok & $34^{\circ} 07^{\prime} 10^{\prime \prime} \mathrm{S}$ & $19^{\circ} 51^{\prime} 10^{\prime \prime} \mathrm{E}$ & $11 / 03 / 2001$ \\
\hline 12 & Leeu & $34^{\circ} 00^{\prime} 00^{\prime \prime} \mathrm{S}$ & $20^{\circ} 20^{\prime} 00^{\prime \prime} \mathrm{E}$ & 09/03/2001 \\
\hline 13 & Melkhout & $34^{\circ} 22^{\prime} 20^{\prime \prime} \mathrm{S}$ & $20^{\circ} 38^{\prime} 20^{\prime \prime} \mathrm{E}$ & $17 / 03 / 2001$ \\
\hline \multicolumn{5}{|c|}{ Duiwenhoks River system } \\
\hline 14 & Duiwenhoks & $34^{\circ} 05^{\prime} 30^{\prime \prime} \mathrm{S}$ & $20^{\circ} 57^{\prime} 40^{\prime \prime} \mathrm{E}$ & 07/03/2001 \\
\hline \multicolumn{5}{|c|}{ Goukou River system } \\
\hline 15 & Kruis & $34^{\circ} 00^{\prime} 52^{\prime \prime} \mathrm{S}$ & $21^{\circ} 17^{\prime} 24^{\prime \prime} \mathrm{E}$ & $26 / 04 / 2000$ \\
\hline \multicolumn{5}{|c|}{ Heuningnes River system } \\
\hline 16 & Grashoek & $34^{\circ} 34^{\prime} 15^{\prime \prime} \mathrm{S}$ & $19^{\circ} 56^{\prime} 45^{\prime \prime} \mathrm{E}$ & $15 / 03 / 2001$ \\
\hline \multicolumn{5}{|c|}{ Tradou catchment (Breede River system) } \\
\hline 17 & Lower Tradou & $33^{\circ} 57^{\prime} 24^{\prime \prime} \mathrm{S}$ & $20^{\circ} 42^{\prime} 28^{\prime \prime} \mathrm{E}$ & $17 / 10 / 2002$ \\
\hline 18 & Tradou tributary & $33^{\circ} 56^{\prime} 51^{\prime \prime} \mathrm{S}$ & $20^{\circ} 42^{\prime} 32^{\prime \prime} \mathrm{E}$ & $1997 / 1998$ \\
\hline 19 & Middle Tradou & $33^{\circ} 56^{\prime} 30^{\prime \prime} \mathrm{S}$ & $20^{\circ} 42^{\prime} 27^{\prime \prime} \mathrm{E}$ & $15-16 / 10 / 2002$ \\
\hline 20 & Upper Tradou & $33^{\circ} 56^{\prime} 07^{\prime \prime} \mathrm{S}$ & $20^{\circ} 42^{\prime} 39^{\prime \prime} \mathrm{E}$ & $18 / 10 / 2002$ \\
\hline 21 & Lower Huis & $33^{\circ} 54^{\prime} 35^{\prime \prime} \mathrm{S}$ & $20^{\circ} 44^{\prime} 24^{\prime \prime} \mathrm{E}$ & $17 / 10 / 2002$ \\
\hline 22 & Middle Huis & $33^{\circ} 54^{\prime} 56^{\prime \prime} \mathrm{S}$ & $20^{\circ} 44^{\prime} 46^{\prime \prime} \mathrm{E}$ & $17 / 10 / 2002$ \\
\hline 23 & Upper Huis & $33^{\circ} 55^{\prime} 09^{\prime \prime} \mathrm{S}$ & $20^{\circ} 45^{\prime} 04^{\prime \prime} \mathrm{E}$ & $17 / 10 / 2002$ \\
\hline
\end{tabular}

Locality 18 was collected by N. D. Impson. All other collections were made by E. R. Swartz and fellow collectors (see acknowledgements)

checked manually. All sequences were deposited in GenBank under accession numbers EU341714EU341754 for cytochrome $b$ and EU341755EU341800 for the control region.

Analysis of genetic variability and phylogeographical structure

The two gene fragments were analysed separately and as concatenated sequences. For each case, the model that best fits the nucleotide substitution pattern for the data was selected from 56 such models based on the Akaike Information Criterion using the programme MODELTEST version 3.06 (Posada \& Crandall, 1998). The
$\mathrm{TIM}+\mathrm{G}$ model was selected for cytochrome $b$, $\mathrm{HKY}+\mathrm{I}$ was selected for the control region and GTR $+\mathrm{G}$ was selected for the combined dataset. Phylogenetic relationships among haplotypes were analysed using Bayesian Inference (BI) as implemented in the programme MrBayes 3.1 (Huelsenbeck \& Ronquist, 2001) using the models selected with MODELTEST. Four simultaneous chains were run for 20 million generations and sampled every 100th generation. The Berg River redfin, $P$. burgi, was used as an outgroup to root the tree. The burn-in value was determined by plotting the average standard deviation of split frequencies, tree length and log-likelihood scores against generation time using the programme 
Tracer v. 1.5 (Rambaut \& Drummond 2007). These plots showed that stationarity was reached within the first $10 \%$ of the trees obtained. Hence, the first 2,000 trees were discarded as burn-in. The remaining 18,000 sampled trees were used to estimate a $50 \%$ majority rule consensus tree and Bayesian posterior probabilities. Two separate BI runs were done for each dataset, and the topology and nodal support of the resulting trees were compared. This was done to assess whether the chains converged to the same point. In all cases, the independent runs gave identical topologies and only slight differences occurred in branch support between runs, indicating that chain lengths were sufficient.

The topologies of the BI trees were compared with those obtained using maximum likelihood (ML) implemented in PAUP (Swofford, 2002) to assess the accuracy with which the phylogenetic relationships could be inferred using the sequence data. The ML analyses were done in PAUP4.0b10, using heuristic tree searches and applying the tree-bisection-reconnection (TBR) branch-swapping algorithm with 10 random addition replicates. Haplotype and nucleotide diversities and their standard errors were calculated for each of the phylogroups identified by the BI and ML analyses. The diversity measures were calculated using the programme ARLEQUIN version 2.000 (Schneider et al., 2000).

Phylogroup divergence dating

Estimates of the timing of phylogroup divergence can help to link the patterns of cladogenesis with known historical climatic or geological events. There are no known fossils for this group, but crude estimates may nonetheless be achieved if a broad range of external mutation rates are used for calibration. This was achieved by setting the boundaries of divergence times using the lowest and highest rates reported for freshwater fishes in the literature. Zardoya \& Doadrio (1999) reported a molecular rate of $0.76 \%$ per million years for European cyprinids, while a rate of $1.3 \%$ was estimated for Luciobarbus based on geological evidence (Machordom \& Doadrio, 2001). Dowling et al. (2002) estimated a rate of $1.05 \%$ per million years for cyprinids based on fossil data. Lipton et al. (2011) estimated rates of 3.84-8.48\% per million years for the mtDNA control region of the North American cyprinid Rhinichthys atratulus. Beast analyses were conducted on the partitioned gene regions using the uniform prior distributions and the highest and lowest rates for each region to estimate the timing of divergence among the $P$. burchelli lineages.

Divergence times were resolved using Bayesian coalescent analysis implemented in the programme BEAST (v. 1.7.2; Drummond et al., 2012). The programme was run using the GTR $+\mathrm{G}$ model of nucleotide substitution, the yule process as the coalescent (tree) prior and the relaxed uncorrelated lognormal molecular clock model. Beast was run for 60 million generations, sampling every 1,000 iterations, with the first $20 \%$ of the trees discarded as burnin. Two chains were run and the results were visualised using TRACER to check for convergence.

\section{Results}

Geographical distances

Geographical distances among localities along the present river courses, the proposed palaeoriver courses and along the $-200 \mathrm{~m}$ contour ranged from 1 to $1106 \mathrm{~km}$. When the present coastline was used to connect the different river systems, geographical distances ranged from 1 to $450 \mathrm{~km}$.

\section{Sequence variation and genetic structuring}

The fragment of control region analysed corresponds with positions 17-615 in Cyprinus carpio (Chang et al., 1994). It yielded 48 variable sites, with 36 parsimony informative (4 with indels) and 12 autapomorphic sites (mutations that were unique to single individuals, 1 with indels), which defined 26 haplotypes in the 46 individuals that were analysed. For cytochrome $b$, the region that corresponds to positions 15,350-16,049 in C. carpio yielded 51 variable sites, with 40 parsimony informative and 11 autapomorphic sites. Twenty haplotypes were detected in the 41 individuals that were analysed. The combined control region and cytochrome $b$ data yielded 26 haplotypes. Of these, haplotypes 1-12 occurred across the Breede River system, haplotype 13 was restricted to the Duiwenhoks River system, haplotype 14 was restricted to the Goukou River system, haplotypes 15-18 were restricted to the Heuningnes River system and haplotypes 19-26 were restricted to the Tradou catchment in the Breede River system (Table 2). 
The phylogenetic trees generated with $\mathrm{BI}$ and $\mathrm{ML}$ based on the concatenated cytochrome $b$ and control region sequences produced identical topologies for three distinct lineages (Fig. 2). All the individuals from the Tradou catchment were included in the most divergent lineage. A Breede lineage consisted of individuals from three presently isolated river systems (the Breede, Duiwenhoks and Goukou) and was closely related to a separate lineage in the Heuningnes River System.

The range of genetic distances among the control region (CR) and cytochrome $b$ (CYT) haplotypes within these identified lineages $\left(D_{\mathrm{CR}}=0-1.5 \% ; D_{\mathrm{CYT}}=\right.$ $0-1.4 \%)$ did not overlap with the genetic distances

Table 2 Frequency of combined control region and cytochrome $b$ haplotypes among sampled localities of the Breede, Heuningnes and Tradou lineages of $P$. burchelli

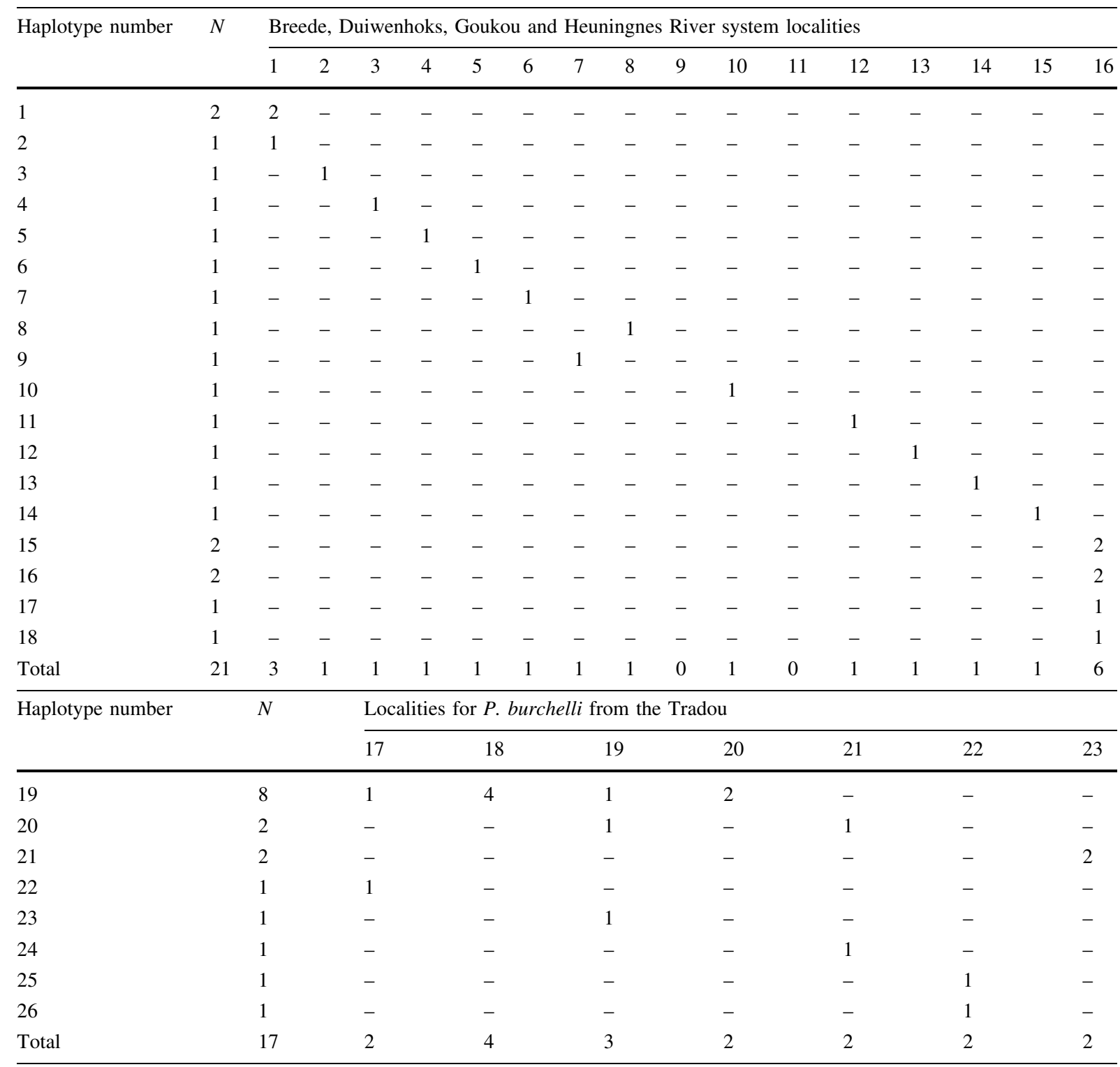

Locality names (See Table 1 for full locality descriptions): 1 Koekedou, 2 Wit, 3 Jan Dutoits, 4 Hex, 5 Nuy, 6 Willem Nels, 7 Hoeks, 8 Kogmanskloof, 9 Baviaans, 10 Gobos, 11 Bok, 12 Leeu, 13 Melkhout, 14 Duiwenhoks, 15 Goukou, 16 Heuningnes

Locality names (See Table 1 for full locality descriptions) 17 Lower Tradou, 18 Tradou tributary, 19 Middle Tradou, 20 Upper Tradou, 21 Lower Huis, 22 Middle Huis, 23 Upper Huis 
Fig. 2 Maximum likelihood tree based on combined control region and cytochrome $b$ sequences showing relationships among the Breede (blue), Heuningnes (red) and Tradou (green) lineages of $P$. burchelli. Haplotype numbers (regular text) and Bayesian posterior probability values (italic text) are also shown

between lineages $\quad\left(D_{\mathrm{CR}}=2.1-6.4 \% ; \quad D_{\mathrm{CYT}}=2.2-\right.$ $6.8 \%)$. The largest genetic distances were between haplotypes of the Tradou lineage and those of the Breede and Heuningnes lineages $\left(D_{\mathrm{CR}}=3.3-6.4 \% ; D_{\mathrm{CYT}}=\right.$ 3.8-6.8\%). Genetic distances were lower between the Breede and Heuningnes lineages $\left(D_{\mathrm{CR}}=2.1-3.3 \%\right.$; $\left.D_{\mathrm{CYT}}=2.2-3.6 \%\right)$. The genetic distances within the Heuningnes lineage $\left(D_{\mathrm{CR}}=0-1.5 \% ; D_{\mathrm{CYT}}=0-1.4 \%\right)$ were much larger compared to the genetic distances within the Breede lineage $\left(D_{\mathrm{CR}}=0-0.7 \% ; D_{\mathrm{CYT}}=\right.$ $0-0.9 \%)$ and the Tradou lineage $\left(D_{\mathrm{CR}}=0-0.9 \%\right.$; $D_{\mathrm{CYT}}=0-0.6 \%$ ). This was surprising since the Heuningnes lineage was only recorded and analysed from a

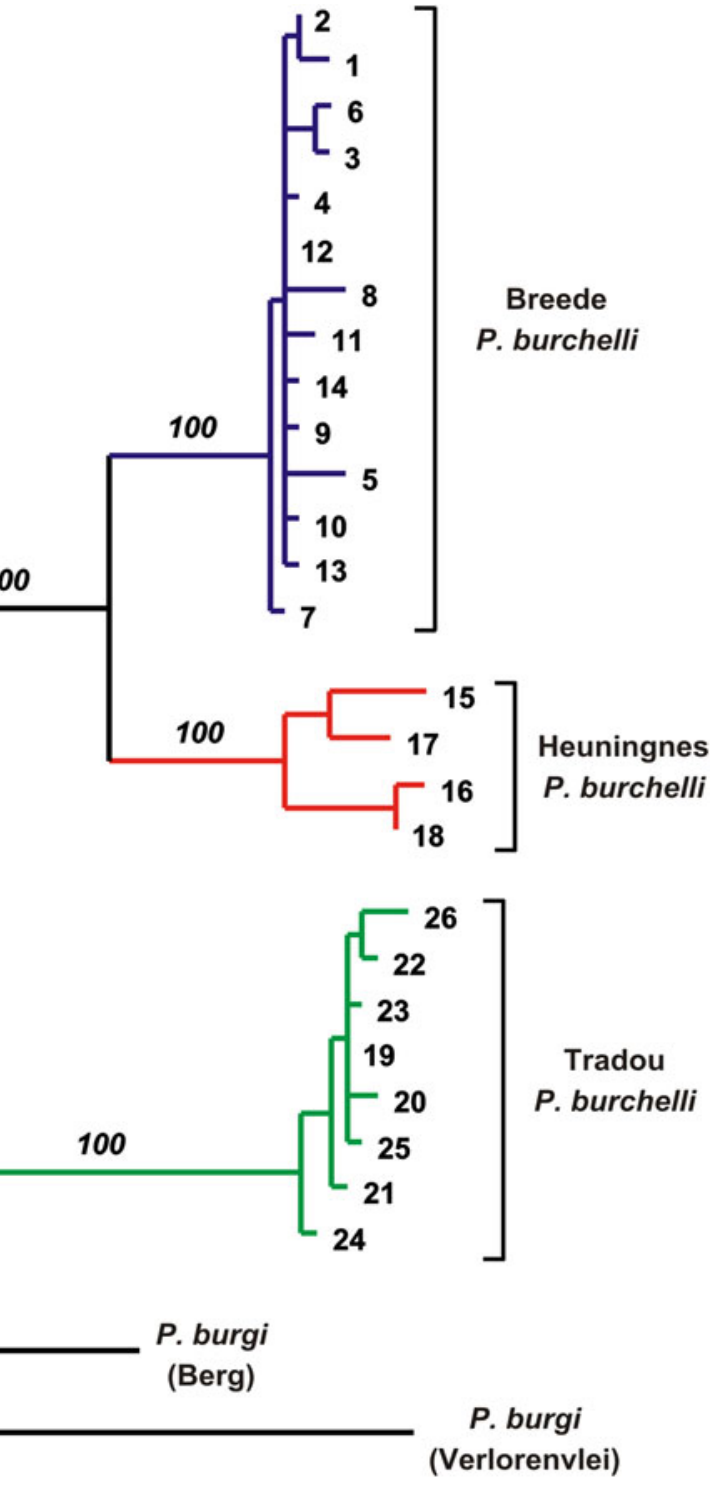

single locality. Gene and nucleotide diversities were lower in the Tradou lineage compared to both the Breede and Heuningnes lineages for the three datasets (Table 3).

\section{Divergence times}

BEAST estimated the divergence of the P. burchelli lineages to have occurred during the Pleistocene epoch (Fig. 3). The Tradou lineage split from the Breede and Heuningnes lineages approximately 1.67 mya $(0.90$ 2.80 mya $95 \%$ HPD), with subsequent divergence between the Breede and Heuningnes estimated to have 
Table 3 Gene $(\delta)$ and nucleotide $(\pi)$ diversity of the Breede, Heuningnes and Tradou lineages of $P$. burchelli for control region, cytochrome $b$ and combined control region and cytochrome $b$ sequences

\begin{tabular}{lccl}
\hline & Control region & Cytochrome $b$ & Combined \\
\hline Gene diversity & & & \\
Breede & $0.958(0.033)$ & $0.850(0.077)$ & $0.991(0.028)$ \\
Heuningnes & $0.867(0.129)$ & $0.893(0.086)$ & $0.867(0.129)$ \\
Tradou & $0.690(0.105)$ & $0.588(0.135)$ & $0.779(0.099)$ \\
Nucleotide diversity & & \\
Breede & $0.009(0.005)$ & $0.003(0.002)$ & $0.003(0.002)$ \\
Heuningnes & $0.211(0.123)$ & $0.007(0.004)$ & $0.009(0.005)$ \\
Tradou & $0.006(0.004)$ & $0.001(0.001)$ & $0.002(0.001)$ \\
\hline
\end{tabular}

Standard errors are shown in brackets

occurred approximately 0.77 mya $(0.25-1.30$ mya 95\% HPD).

\section{Discussion}

Historical causes of genetic differentiation

This study revealed three deeply divergent and strongly supported lineages in $P$. burchelli, with shallow divergences within the lineages. Surprisingly, the largest divergence was found within the Breede River system between the Breede and Tradou lineages. The Tradou lineage is confined to the Tradou catchment, whereas the Breede lineage is one of the most widespread redfin lineages recorded thus far, occurring across the Breede (excluding the Tradou catchment), Duiwenhoks and Goukou river systems. The Heuningnes lineage seems to have the most restricted range among the $P$. burchelli lineages as it was only recorded from a single pool in the Grashoek River, a tributary of the Heuningnes River system, despite surveys at six localities in the Heuningnes and neighbouring Uilkraals River system. Our most recent surveys and results from the surveys done by Russell \& Impson (2006), however, suggest that populations of this lineage survive in the Grashoek, Kars and Nuwejaars catchments of the Heuningnes River system, where they have been recorded before (Barnard, 1943; Skelton, 1988).

Divergence time estimates suggest that the split of the Tradou lineage from the Heuningnes and Breede lineages occurred during the late Pliocene-early Pleistocene, a period characterised by elevated sea levels in southern Africa (Siesser \& Dingle, 1981). Marine incursions during this period could have facilitated fragmentation of river systems (Fig. 1), isolating populations of freshwater taxa in upland refugia. The deep divergence between the Tradou lineage and the other two lineages of $P$. burchelli may be considered as evidence of the marine incursion potentially driving allopatric divergence. Marine incursions have also been considered a driver of divergence of freshwater taxa in North America (Near et al., 2003; Near \& Benard, 2004), the Neotropics (Hubert \& Renno, 2006) and the Indo-Australian Archipelago (de Bruyn \& Mather, 2007). This hypothesis, however, needs to be tested with other codistributed freshwater taxa in the study area.

If only confluence during lower sea levels played a role in connecting populations of $P$. burchelli that are presently isolated in different river systems, the Breede, Duiwenhoks and Heuningnes River systems would have been expected to share a recent history of migration, while the population in the Goukou River system would have been expected to be divergent. This was not the case. While the occurrence of the Breede lineage in both the Breede River and the Duiwenhoks River systems can be explained by the common confluence of these river systems during the lower sea levels of the LGM (Fig. 1), occurrence of this lineage in the Goukou River system cannot be explained by confluence during lower sea levels. Dingle \& Rogers (1972) and Birch (1980) proposed that the Goukou River system had a common confluence with the Gourits River system (Fig. 1). The historical Gourits-Goukou palaeoriver system probably flowed in a southerly direction across the Agulhas Bank, whereas the historical Breede-DuiwenhoksHeuningnes palaeoriver system probably flowed in a south-westerly direction. These two palaeoriver systems would therefore not have had a common confluence during a time frame that is relevant to the evolution of $P$. burchelli.

It is surprising that $P$. tenuis and $P$. asper from the Gourits River system were not able to invade the Goukou River system during the LGM. If $P$. burchelli occurred in the Goukou River system during the LGM, then it is also surprising that this species does not occur in the Gourits River system. It is possible that the Goukou River system was isolated from the 


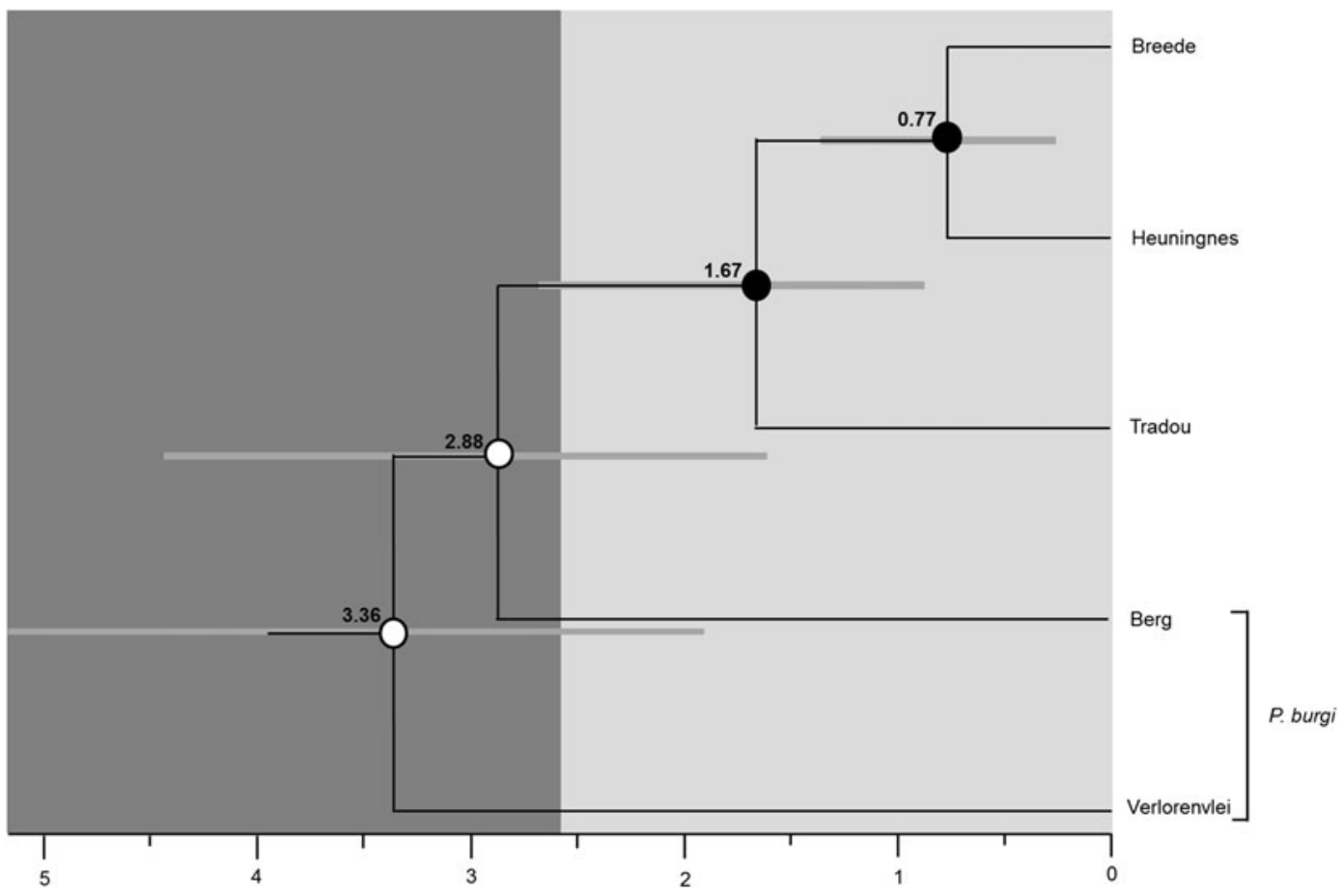

Fig. 3 Chronogram with estimates of divergence times (Ma) of $P$. burchelli lineages using Bayesian coalescent analyses as implemented in BEAST. Mean divergence dates for the in-group lineages are shown above the major divergent nodes. Node bars represent $95 \%$ highest posterior densities for divergence estimates. Solid circles represent posterior proba-bility values greater or equal to 0.95 and the open circle represents a value less than 0.95

mainstream Gourits River system through waterfalls or unsuitable habitat and/or extinctions may have occurred. Alternatively, transfer (for example via a river capture event or human-mediated translocation) of $P$. burchelli to the Goukou River system could have occurred after the LGM and therefore after the Gourits and the Goukou River systems were isolated from each other.

A river capture between the Duiwenhoks and Goukou River systems would have had to be relatively recent to explain the low divergence between the Goukou and the Breede-Duiwenhoks populations of the Breede lineage. The three river systems have broadly similar habitats which could have allowed the Breede lineage to survive with minimal adaptation after a river capture event. Alternatively, the occurrence of the Breede lineage in the Goukou River system could be as a result of the recent translocation by humans. Additional markers and larger sample sizes are required to resolve this.

Most of the southern coastal lowland areas that are now drained by the Heuningnes, Duiwenhoks and
Goukou River systems would have been drowned during the early Pliocene transgression (Fig. 1). The colonisation of the Heuningnes River system by $P$. burchelli is therefore more recent than the early Pliocene transgression. This colonisation could have occurred as a result of the confluence of the historical Breede-Duiwenhoks palaeoriver and the Heuningnes River. Divergence time estimates from this study, however, indicate that the divergence of $P$. burchelli lineages predates the LGM regression, suggesting that isolation occurred earlier. This raises the possibility that the Heuningnes and the historical Breede-Duiwenhoks palaeoriver never had a common confluence before reaching the $-130 \mathrm{~m}$ LGM sea level and that $P$. burchelli reached the Heuningnes River system through other mechanisms. That requires the Heuningnes to have flowed in a much further westerly position than what has been indicated in Fig. 1. Even then, a common confluence with the Breede-Duiwenhoks palaeoriver during the LGM seems likely.

It is possible that extreme ecological gradients between the Heuningnes and Breede could have 
prevented exchange of lineages between the two systems. The Heuningnes is characterised by higher water conductivity, generally higher turbidity and lower gradients compared to tributaries of the Breede. The present distribution of the lineages could then be attributed to the differences in the environments that they inhabit. Habitat preference could therefore explain why both lineages do not occur in both river systems, considering that the LGM connection would only have been about 18,000 years ago. Bloomer \& Impson (2000) reported a similar situation for the Berg River redfin. They found eutrophic adapted (Verlorenvlei River system) and oligotrophic adapted (Berg River system) lineages within $P$. burgi, but the divergence between these two lineages is much older than that between the Heuningnes and Breede lineages of $P$. burchelli. Alternatively, the potential presence of waterfalls in the offshore reaches between the Heuningnes River and the historical Breede-Duiwenhoks palaeoriver may have formed barriers that could have prevented dispersal of the lineages between the two systems.

It was unexpected that the oldest divergence was between the Tradou lineage and the other two $P$. burchelli lineages, because the Tradou is a relatively small catchment within the Breede River system. A waterfall marks the lower limit of the distribution of the Tradou lineage, which would have prevented upstream gene flow. Downstream migration might have been possible, but no evidence of introgression of mtDNA haplotypes between the Tradou and Breede lineages was found in the present study. It is therefore possible that the Tradou lineage was either never in contact with the Breede lineage or that it was not able to breed with the Breede lineage in areas where their distributions overlapped. Alien fishes now dominate the river below the waterfall, where the overlap between these two lineages would have been most likely. A direct assessment of whether these two lineages can interbreed can therefore not be done in their natural environment.

Waterfalls can influence speciation of freshwater fishes. For example, Kano et al. (2012) found that waterfalls played an important role in the differentiation of Rhinogobius populations in Japan. Within the CFR, speciation of Barbus erubescens and B. calidus was probably aided by waterfalls in the Twee River catchment (Olifants River system), which mark the lower distributional limit for B. erubescens (Skelton,
1974; Swartz et al., 2004). These waterfalls would have prevented upstream gene flow, but it is surprising that B. erubescens did not spread to the rest of the Olifants River system. Similarly, it is surprising that the Tradou lineage of $P$. burchelli did not extend its range in the Breede River system. This may suggest that ecological gradients are playing a role, but further studies are required to compare the ecological attributes of the Tradou and Breede lineages of $P$. burchelli.

Another reason may be competition avoidance. Apart from the long fin eel (Anguilla mossambica), no other indigenous fishes were recorded with the Tradou lineage of $P$. burchelli. The Breede lineage of $P$. burchelli may be better adapted to compete with other native fishes (e.g. Sandelia capensis and Galaxias zebratus) that are broadly co-distributed with this lineage. A similar argument was proposed as a reason why $B$. erubescens did not extend its range in the Olifants River system, since historically it only occurred with the much smaller Galaxias zebratus (Skelton, 1974; Swartz et al., 2004). This raises the possibility that parapatric speciation could have occurred between the Tradou lineage and a BreedeHeuningnes ancestor. Given the possibility of downstream gene flow, some level of ecological speciation reinforced by breeding segregation would have had to occur.

Taxonomic and conservation implications

The results of this study require that the taxonomic status of the Breede, Heuningnes and Tradou lineages be investigated. Several taxonomic changes will have to be made if these lineages are found to be both genetically and morphologically divergent. The Breede, Heuningnes and Tradou lineages can be considered to be evolutionarily significant units (ESUs) according to the definition of Moritz (1994). The historical isolation processes that have led to the divergence of these lineages should be allowed to continue, by keeping these lineages isolated and by conserving the different habitats in which they occur. The low levels of differentiation within the Breede and Tradou lineages suggest that historical restricted gene flow should be restored. In the case of the Breede lineage, it may be difficult to restore corridors between the currently isolated populations, but at least 20 populations of this lineage were recorded during the present study and subsequent surveys. If the sizes of these populations are 
large enough to prevent local inbreeding, most of the genetic diversity can be effectively conserved by maintaining these populations.

Urgent conservation actions are needed to secure the survival of both the Heuningnes and Tradou lineages. Habitat rehabilitation and eradication of alien fishes are required for both lineages. Very few options are available for the Heuningnes lineage, but upstream areas will have to be found where populations can be secured from invasion by alien fishes. The river reach area from Tradou's Pass to above the town of Barrydale can be rehabilitated. Restoring a corridor between these two fragmented populations will allow gene flow and the possibility to maintain a larger effective population size.

Acknowledgements For assistance in the field, we thank Roger Bills, Daksha Naran, John Grigg, Heidi Roos, Roelien van Niekerk and Krystal Tolley. John Grigg made us aware that the Tradou population might be potentially unique and collected museum vouchers with Dean Impson. WWF (Table Mountain Fund and Prince Bernhard Scholarships), the National Research Foundation (South Africa) and the Claude Leon Foundation funded the research.

\section{References}

Barnard, K. H., 1943. Revision of the indigenous freshwater fishes of the S.W. Cape region. Annals of the South African Museum 36: 101-263.

Birch, G. F., 1980. Nearshore Quaternary Sedimentation off the South Coast of South Africa (Cape Town to Port Elizabeth). Unpublished Report. Council for Geoscience, Pretoria, Pretoria.

Bloomer, P. \& N. D. Impson, 2000. Mitochondrial DNA differentiation in the critically endangered Berg River Redfin (Pseudobarbus burgi). The Journal of Heredity 91: 122-127.

Brito, R. M., J. Briolay, N. Galtier, Y. Bouvet \& H. Coelho, 1997. Phylogenetic relationships within genus Leuciscus (Pisces, Cyprinidae) in Portuguese fresh waters, based on mitochondrial DNA cytochrome $b$ sequences. Molecular Phylogenetics and Evolution 8: 435-442.

Burridge, C. P., D. Craw, D. C. Jack, T. M. King, J. M. Waters \& K. Crandall, 2008. Does fish ecology predict dispersal across a river drainage divide? Evolution 62: 1484-1499.

Butzer, K. W. \& D. M. Helgren, 1972. Late Cenozoic evolution of the Cape Coast between Knysna and Cape St. Francis, South Africa. Quaternary Research 2: 143-169.

Chakona, A., E. R. Swartz, G. Gouws \& P. Bloomer, 2013. A freshwater fish defies ancient mountain ranges and drainage divides: extrinsic and intrinsic influences on the evolutionary history of a recently identified galaxiid. Journal of Biogeography 40: 1399-1412.

Chang, Y. S., F. L. Huang \& T. B. Lo, 1994. The complete nucleotide sequence and gene organization of carp
(Cyprinus carpio) mitochondrial genome. Journal of Molecular Evolution 38: 138-155.

Crandall, K. A., O. R. P. Bininda-Emonds, G. M. Mace \& R. K. Wayne, 2000. Considering evolutionary processes in conservation biology. Trends in Ecology and Evolution 15: 290-295.

Craw, D., C. Burridge, L. Anderson \& J. M. Waters, 2007. Late Quaternary river drainage and fish evolution, Southland, New Zealand. Geomorphology 84: 98-110.

Day, J. A., H. F. Dallas \& A. Wackernagel, 1998. Delineation of management regions for South African rivers based on water chemistry. Aquatic Ecosystem Health and Management 1: 183-197.

de Bruyn, M. \& P. B. Mather, 2007. Molecular signatures of Pleistocene sea-level changes that affected connectivity among freshwater shrimp in Indo-Australian waters. Molecular Ecology 16: 4295-4307.

de Bruyn, M., E. Nugroho, M. M. Hossain, J. C. Wilson \& P. B. Mather, 2004. Phylogeographic evidence for the existence of an ancient biogeographic barrier: the Isthmus of Kra Seaway. Heredity 94: 370-378.

Dingle, R. V. \& J. Rogers, 1972. Pleistocene palaeogeography of the Agulhas Bank. Transactions of the Royal Society of South Africa 40: 155-165.

Dingle, R. V., G. F. Birch, J. M. Bremner, R. H. De Decker, A. Du Plessis, J. C. Engelbrecht, M. J. Fincham, T. Fitton, B. W. Flemming, R. I. Gentle, S. W. Goodlad, A. K. Martin, E. G. Mills, G. J. Moir, R. J. Parker, S. H. Robson, J. Rogers, D. A. Salmon, W. G. Siesser, E. S. W. Simpson, C. P. Summerhayes, F. Westall, A. Winter \& M. W. Woodborne, 1987. Deep-sea sedimentary environments around southern Africa (South-east Atlantic and South-west Indian Oceans). Annals of the South African Museum 98: 1-27.

Dowling, T. E., C. A. Tibbets, W. L. Minckley \& G. R. Smith, 2002. Evolutionary relationships of the plagopterins (Teleostei: Cyprinidae) from cytochrome $b$ sequences. Copeia 2002: 665-678.

Drummond, A. J., M. A. Suchard, D. Xie \& A. Rambaut, 2012. Bayesian phylogenetics with BEAUti and the BEAST 1.7. Molecular Biology and Evolution 29: 1969-1973.

Hubert, N. \& J.-F. Renno, 2006. Historical biogeography of South American freshwater fishes. Journal of Biogeography 33: 1414-1436.

Huelsenbeck, J. P. \& F. Ronquist, 2001. MrBayes: Bayesian inference of phylogenetic trees. Bioinformatics 17: 754-755.

Kano, Y., S. Nishida \& J. Nakajima, 2012. Waterfalls drive parallel evolution in a freshwater goby. Ecology and Evolution 2: 1805-1817.

Ketmaier, V., P. G. Bianco, M. Cobolli, M. Krivokapic, R. Caniglia \& E. De Matthaeis, 2004. Molecular phylogeny of two lineages of Leuciscinae cyprinids (Telestes and Scardinius) from the peri-Mediterranean area based on cytochrome $b$ data. Molecular Phylogenetics and Evolution 32: 1061-1071.

Keyser, N., 1998. Geological map of the Republic of South Africa. Council for Geoscience, Pretoria.

Lipton, M. L., S. Gignoux-Wolfshon, P. Stonebraker \& B. Chernoff, 2011. Postglacial recolonization of eastern Blacknose Dace, Rhinichthys atratulus (Teleostei: Cyprinidae), through the gateway of New England. Ecology and Evolution 2011: 343-358. 
Machordom, A. \& I. Doadrio, 2001. Evidence of a cenozoic Betic-Kabilian connection based on freshwater fish phylogeography (Luciobarbus, Cyprinidae). Molecular Phylogenetics and Evolution 18: 252-263.

Mesquita, N., G. Carvalho, P. Shaw, E. Crespo \& M. M. Coelho, 2001. River basin-related genetic structuring in an endangered fish species, Chondrostoma lusitanicum, based on mtDNA sequencing and RFLP analysis. Heredity 86: 253-264.

Moritz, C., 1994. Defining "evolutionarily significant units" for conservation. Trends in Ecology and Evolution 9: 373-375.

Moritz, C., 1999. Conservation units and translocations: strategies for conserving evolutionary processes. Hereditas 130: 217-228.

Moritz, C., 2002. Strategies to protect biological diversity and the evolutionary processes that sustain it. Systematic Biology 51: 238-254.

Near, T. J. \& M. F. Benard, 2004. Rapid allopatric speciation in logperch darters (Percidae: percina). Evolution 58: 2798-2808.

Near, T. J., T. W. Kassler, J. B. Koppelman, C. B. Dillman \& D. P. Philipp, 2003. Speciation in North American black basses, Micropterus (Actinopterygii: Centrarchidae). Evolution 57: 1610-1621.

Posada, D. \& K. A. Crandall, 1998. MODELTEST: testing the model of DNA substitution. Bioinformatics 14: 817-818.

Rambaut, A. \& A. J. Drummond, 2007. Tracer v.1.4. Available from: http://beast.bio.ed.ac.uk/Tracer.

Ramsay, P. J. \& J. A. G. Cooper, 2002. Late Quaternary sealevel change in South Africa. Quaternary Research 57: 82-90.

Rogers, J., 1985. Geomorphology, offshore bathymetry and quaternary lithostratigraphy around the Bot River estuary. Transactions of the Royal Society of South Africa 45: 211-227.

Russell, I. A. \& N. D. Impson, 2006. Aquatic systems in and adjacent to Agulhas National Park with particular reference to the fish fauna. Koedoe 49: 45-57.

Sambrook, J., E. F. Fritsch \& T. Maniatis, 1989. Molecular cloning: a laboratory manual. Cold Spring Harbour Laboratory Press, New York.

Schneider, S., D. Roessli, \& L. Excoffier, 2000. Arlequin version 2.000: A software for population genetic data analysis. Genetics and Biometry Laboratory, University of Geneva, Geneva.

Siesser, W. G. \& R. V. Dingle, 1981. Tertiary sea-level movements around southern Africa. Journal of Geology 89: 83-96.

Skelton, P. H., 1974. A new Barbus species from the Olifants River System, Western Cape Province, South Africa. J. L.
B. Smith Institute of Ichthyology Special Publication 13: $1-12$.

Skelton, P. H., 1987. South African red data book-fishes. South African National Scientific Programmes Report 137. Council for Scientific and Industrial Research, Pretoria.

Skelton, P. H., 1988. A taxonomic revision of the redfin minnows (Pisces, Cyprinidae) from southern Africa. Annals of the Cape Provincial Museum (Natural History) 16: 201-307.

Smith, A., 1841. Pisces. Illustrations of the Zoology of South Africa. Smith, Elder and Col., London.

Swartz, E. R., A. F. Flemming, \& P. Le F. N. Mouton, 2004. Contrasting genetic patterns and population histories in three threatened redfin species (Cyprinidae) from the Olifants River System, western South Africa. Journal of Fish Biology 64: 1153-1167.

Swartz, E. R., P. H. Skelton \& P. Bloomer, 2007. Sea-level changes, river capture and the evolution of populations of the Eastern Cape and fiery redfins (Pseudobarbus afer and Pseudobarbus phlegethon, Cyprinidae) across multiple river systems in South Africa. Journal of Biogeography 34: 2086-2099.

Swartz, E. R., P. H. Skelton \& P. Bloomer, 2009. Phylogeny and biogeography of the genus Pseudobarbus (Cyprinidae): shedding light on the drainage history of rivers associated with the Cape Floristic Region. Molecular Phylogenetics and Evolution 51: 75-84.

Swofford, D. L., 2002. PAUP* Phylogenetic Analysis Using Parsimony (*and Other Methods), Version 4. Sinauer Associates, Sunderland.

Tankard, A. J., 1976. Cenozoic sea-level changes: a discussion. Annals of the South African Museum 71: 1-17.

Thompson, J. D., T. J. Gibson, T. F. Plewniak, F. Jeanmougin \& D. G. Higgins, 1997. The Clustal X windows interface: flexible strategies for multiple sequence alignment aided by quality analysis tools. Nucleic Acids Research 24: 4876-4882.

Waters, J. M. \& J. A. Cambray, 1997. Intraspecific phylogeography of the Cape galaxias from South Africa: evidence from mitochondrial DNA sequences. Journal of Fish Biology 50: 1329-1338.

Waters, J. M. \& G. P. Wallis, 2000. Across the Southern Alps by river capture? Freshwater fish phylogeography in South Island, New Zealand. Molecular Ecology 9: 1577-1582.

Wong, B. B. M., J. S. Keogh \& D. J. McGlashan, 2004. Current and historical patterns of drainage connectivity in eastern Australia inferred from population genetic structuring in a widespread freshwater fish Pseudomugil signifer (Pseudomugilidae). Molecular Ecology 13: 391-401.

Zardoya, R. \& I. Doadrio, 1999. Molecular evidence on the evolutionary and biogeographical patterns of European cyprinids. Journal of Molecular Evolution 49: 227-237. 